\title{
Mechanisms of pigmentation loss in subterranean fishes
}

\author{
Vanessa Felice $^{1}$, Maria Aparecida Visconti ${ }^{2}$ and Eleonora Trajano ${ }^{1}$
}

Troglobitic (exclusively subterranean) organisms usually present, among their apomorphies related to the subterranean life (troglomorphisms), the regression of eyes and melanic pigmentation. The degree of regression varies among species, from a slight reduction to the complete loss of eyes and dark pigmentation, without a taxonomic correlation. While mechanisms of eye reduction have been intensively investigated in some troglobites such as the Mexican blind tetra characins, genus Astyanax, and the European salamander, Proteus anguinus, few studies have focused on pigmentation. The Brazilian subterranean ichthyofauna distinguishes not only by the species richness ( 23 troglobitic fishes so far known) but also by the variation in the degree of reduction of eyes and pigmentation. This study focused on Brazilian fishes completely devoid of melanic pigmentation: the characiform Stygichthys typhlops (Characidae) and the siluriforms Ancistrus formoso (Loricariidae), Rhamdiopsis sp.1 (Heptapteridae; from caves in the Chapada Diamantina, Bahia) and Rhamdiopsis sp. 2 (cave in Campo Formoso, Bahia). In order to investigate if such depigmentation is the result of blockage in some step in the melanogenesis, in vitro tests of administration of L-DOPA were done, using caudal-fin fragments extracted from living fish. Except for Rhamdiopsis sp. 2, all the studied species were DOPA(+), i.e., melanin was synthesized after L-DOPA administration. This indicates these fish do have melanophores but they are unable to convert L-tyrosine to L-DOPA. On the other hand, Rhamdiopsis sp. 2, like the albino specimens of Trichomycterus itacarambiensis previously studied (which correspond to one third of the population), are DOPA $(-)$, either because the block of melanin synthesis occurs downstream in melanogenesis, which is probably the case with T. itacarambiensis (monogenic system in view of the phenotypic discontinuity), or because the so-called albinos do no possess melanophores. The physiological loss in the ability to synthesize melanin, apparently caused by different genetic processes in $\operatorname{DOPA}(+)$ and in DOPA(-) fishes, may co-exist in subterranean populations with a decrease in the density of melanophores, as observed in the pigmented two thirds of T. itacarambiensis population, a morphological reduction apparently controlled by polygenic systems producing a continuous phenotypic variation.

Organismos exclusivamente subterrâneos (troglóbios) usualmente exibem, entre as apomorfias relacionadas à evolução em isolamento nesse ambiente (troglomorfismos), a redução, até perda total, das estruturas visuais e da pigmentação melânica. Os mecanismos de regressão ocular em troglóbios têm sido intensivamente estudados, sobretudo em peixes como os lambaris cegos mexicanos do gênero Astyanax, e salamandras como Proteus anguinus. Por outro lado, poucos são os trabalhos abordando a perda da pigmentação nesses organismos. A ictiofauna subterrânea brasileira destaca-se não só pela riqueza de espécies (23 conhecidas até o momento) como também pelas diferenças no seu grau de troglomorfismo, sem uma correlação taxonômica. O presente estudo abordou as espécies brasileiras totalmente desprovidas de qualquer traço de pigmentação melânica: o caraciforme Stygichthys typhlops (Characidae) e os siluriformes Ancistrus formoso (Loricariidae), Rhamdiopsis sp.1 (Heptapteridae; cavernas da Chapada Diamantina, Bahia) e Rhamdiopsis sp. 2 (caverna de Campo Formoso, Bahia). Com a finalidade de investigar se essa despigmentação é resultado de bloqueio em algum passo da cadeia de síntese de melanina, foram feitos testes in vitro, utilizando-se fragmentos da nadadeira caudal extraídos de exemplares mantidos vivos, de reação à administração de L-DOPA. Com exceção dos de Rhamdiopsis sp. 2, os exemplares estudados revelaram-se DOPA $(+)$, i.e., houve produção de melanina após a administração de L-DOPA, o que indica que sua despigmentação é devida a uma disfunção da tirosinase, enzima responsável pela transformação de tirosina em L-DOPA nos melanóforos, os quais, portanto, ainda existem nesses peixes. Já os exemplares Rhamdiopsis sp. 2, assim como o terço conspicuamente despigmentado da população de Trichomycterus itacarambiensis, espécie estudada anteriormente sob esse aspecto, são DOPA(-), seja porque o bloqueio na síntese de melanina ocorre em um passo a jusante da produção de L-DOPA, aparentemente o caso de T. itacarambiensis (herança monogênica em vista da descontinuidade fenotípica), ou porque houve perda total dos melanóforos. A perda fisiológica da capacidade de sintetizar melanina, aparentemente causada por diferentes mecanismos nas populações DOPA $(+)$ e naquelas DOPA(-), pode co-existir com a redução no número e tamanho dos melanóforos, como observado nos dois terços pigmentados de T. itacarambiensis, provavelmente determinada por herança poligênica, que produz uma distribuição contínua de fenótipos.

Key words: Caves, Physiology of pigmentation, Character regression, Melanocytes, Troglobites, Brazil.

'Departamento de Zoologia, Instituto de Biociências da USP, C.P. 11461, 05422-970 São Paulo, SP, Brazil. (VF) vanessa-felice@ig.com. br; (ET) etrajano@usp.br

${ }^{2}$ Departamento de Fisiologia, Instituto de Biociências da USP, Rua do Matão, trav. 14, n³21, 05508-900 São Paulo, SP, Brazil. (MAV) maviscon@usp.br 


\section{Introduction}

Subterranean communities have three basic components, each with representatives of several different taxa: troglophilic populations of species also living aboveground, formed by individuals which can complete their life cycles on the subterranean environment (some commute between surface and hypogean habitats, maintaining the genetic connectiveness within the species); trogloxenic populations, formed by individuals regularly found in subterranean habitats, but which must go aboveground to complete their life cycles; and troglobitic species (exclusively subterranean), which differentiate in isolation in the hypogean environment, becoming unable to complete life cycles aboveground (Trajano, 2005).

The most frequent and conspicuous autapomorphies of troglobites are the reduction, till complete loss, of visual organs and dark pigmentation (melanin, in vertebrates). In view of their structural complexity, it is not surprising that the reduction of eyes in troglobitic vertebrates (salamanders and fishes) has been intensively investigated, with focus on micro- and ultra-structure, genetics and developmental biology. Nevertheless, such studies are concentrated on a few taxa, mainly the troglobitic Mexican tetra characins, genus Astyanax, and the European salamander, Proteus anguinus, found in the Dinaric karst.

In contrast, detailed studies on the reduction of pigmentation in subterranean organisms are much less frequent, but also concentrated on the above taxa. Such studies point to different morphological and physiological evolutionary mechanisms, which are not mutually exclusive, leading to the reduction of melanic pigmentation. In fish taxa showing variation in color, the density of melanophores (number of dark cells per unit of body area) is decreased in paler individuals, as is the case of Astyanax from Sabinos and Piedras caves (Wilkens, 1988), and the Brazilian cave catfish, Pimelodella spelaea (Trajano et al., 2004). On the other hand, some populations are completely devoid of melanin, probably due to the loss of ability to synthesize melanin, as observed for other studied cave populations of Astyanax (Wilkens, 1988; Jeffery, 2005, 2006) and for one third of the single population of the Brazilian catfish Trichomycterus itacarambiensis (Trajano \& Pinna, 1996), or even the loss of pigment cells themselves.

Different, independently inherited gene systems are responsible by these changes. The number of melanophores would be determined by an additively polygenic system (Wilkens, 1988), which is consistent with the continuous distribution of color phenotypes in several subterranean fishes. The ability to synthesize melanin, on the other hand, would be controlled by monogenic, recessive systems (Wilkens, 1988), which is consistent with the discontinuous distribution of colorless versus colored phenotypes in cavefish as $T$. itacarambiensis (Trajano \& Pinna, 1996).

The color in heterothermic vertebrates is determined mainly by the presence of pigment cells (chromatophores) in the dermis. Color patterns are the result of combination of different types of pigment cells, their densities and distribu- tion on the body surface. The most conspicuous and widely distributed vertebrate pigment cells are the melanophores, which synthesize dark pigments (melanins) from its precursor, L-tyrosine, an essential amino acid.

Melanogenesis has been intensively investigated in mammals. The enzyme tyrosinase catalyzes the two first steps in this chain, respectively L-tyrosine hydroxylation to 3,4-dihydroxyphenylalanine (L-DOPA) and oxidation of L-DOPA to dopaquinone (Yamaguchi et al., 2007). In the other steps of melanogenesis two tyrosinase-related enzymes, TRP-1 and TRP-2 (DOPAchrome tautomerase) play roles, and these steps result in the oxidative linkage of several indole compounds, producing eumelanin, black or dark brown in color. In the pheomelanin synthesis, yellow to reddish brown, only tyrosinase is involved (Yamaguchi et al., 2007)

Melanogenesis occurs inside cytoplasmatic organelles called melanosomes, which pass through several maturation steps. The first stage might be common in eu- and pheomelanogenesis, and is derived from endosomes. In the following stages, during eumelanogenesis the melanosomes contain filaments and/or well organized lamellas, and with deposit of melanin they become electron-dense and amorphous when completely mature. In contrast, in those melanosomes in which there is synthesis of pheomelanin only material with grain aspect is observed in all the maturation phases. (Jimbow et al., 2000).

The Brazilian troglobitic ichthyofauna is one of the richest in the world, encompassing species in different degrees of reduction of eyes melanic pigmentation (Trajano \& Bichuette, 2005). This diversity provides excellent opportunities for comparative studies aiming to uncover the mechanisms leading to such reductions. So far, 24 species (seven still undescribed) belonging to the three ostariophysan orders, six families and 13 genera have been found in Brazilian subterranean habitats (Trajano \& Bichuette, 2005; Mattox et al., 2008), from caves to ground waters in alluvial fans (Trajano, 2001). Moreover, in some cases morphological (Reis et al., 2006) and molecular studies (Borowsky \& Bichuette, pers. comm.) indicated that subsets of some species are evolving in some isolation, thus the number of taxonomic units may be larger.

During the last years, we have kept alive fish belonging to 18 Brazilian troglobitic species, including four completely depigmented, without any trace of melanin (Stygichthys typhlops, Ancistrus formoso, Taunayia sp. from Campo Formoso, Bahia, and Rhamdiopsis sp. from Chapada Diamantina, Bahia), in addition to both pigmented and depigmented specimens of T. itacarambiensis. The aim of this paper was to investigate physiological mechanisms involved in melanogenesis in colorless subterranean fishes.

\section{Material and Methods}

Specimens belonging to four troglobitic species kept in our laboratory were tested: the phreatobic characiform Stygichthys typhlops (Characidae), four specimens collected in artificial wells in Jaíba Co., State of Minas Gerais, eastern Brazil; 
and the siluriforms Ancistrus formoso (Loricariidae), three specimens from a flooded cave, the Formoso Resurgence, in Bonito Co., State of Mato Grosso do Sul, southwestern Brazil; Rhamdiopsis sp.1 (Heptapteridae), 11 specimens from five caves in Chapada Diamantina, State of Bahia, northeastern Brazil; and "Taunayia" sp. (Heptapteridae), five specimens from the single known locality, Toca do Gonçalo Cave, in Campo Formoso, State of Bahia. According to F.A.Bockmann (pers. comm..), the troglobitic heptapterid from Toca do Gonçalo, previously cited as Taunayia sp. (e.g., Trajano \& Bockmann, 1999; Trajano, 2003), actually belongs to the genus Rhamdiopsis, and will be herein referred to as Rhamdiopsis sp.2. All these fishes are highly specialized, presenting low population densities, what limited our sample sizes. For comparison, we also tested four Mexican blind tetra characins from a commercial stock (most of these stocks originally came from La Chica Cave). We also included data on completely depigmented ("albinic") specimens of Trichomycetrus itacarambiensis (Trichomycteridae), endemic to the Olhos d'Água Cave, northern State of Minas Gerais, previously obtained using the same methods (Trajano \& Pinna, 1996).

In order to investigate the melanin synthesis in these fishes in vitro experiments were performed, supplying L-DOPA to 3-5 $\mathrm{mm}^{2}$ caudal-fin clippings and observing whether cells with melanin inclusions were observed or not. Due to the small size of the fish, fin fragments of different individuals (except for the relatively large $A$. formoso) were used in control experiments, in which the same in vitro procedures were applied, excluding the L-DOPA from the solutions. Each individual was tested once.

We used the same general steps of the method described by Mishima (1960) and Hirobe (1982). Fragments of the upper lobe of caudal fins were removed from alive, non-anesthetized fish, using small surgical scissors. These fragments were incubated in a phosphate-buffered solution with $5 \%$ of formalin $(\mathrm{pH}=7.0)$, for $30 \mathrm{~min}$ at $4^{\circ} \mathrm{C}$, washed twice with distilled water, and then incubated in a phosphate-buffered solution $\left(\mathrm{pH}=6.8\right.$ ) with $0.1 \%$ of L-DOPA, for $3.5 \mathrm{~h}$, at $37^{\circ} \mathrm{C}$; and after $1.5 \mathrm{~h}$ from the beginning of the $3.5 \mathrm{~h}$ treatment, the solution was replaced by a fresh one. After this incubation period the L-DOPA solution was substituted by a phosphate buffered solution with $10 \%$ formalin $(\mathrm{pH}=7.0)$ and the fin fragments remained for a further hour at $25^{\circ} \mathrm{C}$. For controls, only phosphate buffered solution ( $\mathrm{pH}=6.8$ ), without L-DOPA, was employed. Specimens where pigment cells were in evidence following the in vitro tests were classified as DOPA (+), and those in which it was impossible to distinguished any pigmented cells, as DOPA (-) (as in Trajano \& Pinna, 1996).

\section{Results}

The results of the tests in term of positive or negative response to DOPA are shown in Table 1. In no case, pigment cells were observed in control fish. No intra- or inter-population variations were observed for the studied species. These fish, including the Mexican tetras, were classified as DOPA (+), except for Rhamdiopsis sp.2 ("Taunayia" sp.), which did not respond to the administration of L-DOPA. No pigmented cells were visible in the controls.

Selected fin fragments are shown in Figs. 1 to 4. Figs. 1 and 2 show a detail of a fragment of the caudal-fin of one specimen of Stygichthys typhlops, respectively before (control) and after administration of L-DOPA, illustrating its DOPA $(+)$ condition (melanin cells are visible). Figs. 3 and 4 show, respectively, a detail of fragments of the caudal-fin of a pigmented and of a DOPA(-) albino specimen of T. itacarambiensis.

At least some of the melanin cells visible in $\mathrm{DOPA}(+)$ specimens after the treatment were stellate, indicating that these cells were differentiated melanophores (sensu McCauley et al., 2004).

\section{Discussion}

In his classical review on Mexican cave Astyanax, Wilkens (1988) mentions two main mechanisms underlying the reduction of dark pigmentation in cavefish, a morphological (decrease in the number and size of melanophores = "partial reduction" of pigmentation) and a physiological one (lack of melanin), characteristic of "albinotic" populations, such as those from Pachon and Yerbaniz caves. These conclusions were based on traditional genetic studies using lineage crossings. A different approach, based on developmental molecular biology, was recently applied by McCauley et al. (2004) in the study of the cavefish Astyanax. These authors concluded that the melanoblasts of depigmented fish are unable to convert L-tyrosine to L-DOPA, indicating a deficiency in tyrosine uptake and/or utilization.

During the last two decades, the molecular approach has been increasingly used in genetic studies on pigmentation disorders such as the oculocutaneous albinism (OCA), characterized by a reduced or absent biosynthesis of melanin pigment in melanocytes of the skin, hair follicles and eyes. The OCA type 1 (tyrosinase-negative) and OCA type 3 (TRP1) are caused respectively by gene mutations leading to the

Table 1. Reaction to DOPA in depigmented cave fishes, showing the presence $(+)$ or not $(-)$ of melanin cells in fin-clippings after the administration in vitro of L-DOPA. $\mathrm{N}=$ number of specimens tested; $\mathrm{MG}=$ State of Minas Gerais, eastern Brazil (São Francisco basin). MS = State of Mato Grosso do Sul, southwestern Brazil (Paraguay basin); BA = State of Bahia, northeastern Brazil (São Francisco basin).

\begin{tabular}{|c|c|c|c|}
\hline Species & Locality & $\mathbf{N}$ & $\begin{array}{c}\text { Reaction to } \\
\text { DOPA }\end{array}$ \\
\hline$\overline{\text { Stygichthys typhlops }}$ & Well in Jaíba (MG) & 4 & + \\
\hline Ancistrus formoso & Formoso resurgence (MS) & 3 & + \\
\hline Rhamdiopsis sp. & Moreno Cave (BA) & 4 & + \\
\hline Rhamdiopsis sp. & Poço Encantado Cave (BA) & 1 & + \\
\hline Rhamdiopsis sp. & Natal Cave (BA) & 3 & + \\
\hline Rhamdiopsis sp. & Torrinha Cave (BA) & 1 & + \\
\hline Rhamdiopsis sp. & Canoa Quebrada Cave (BA) & 2 & + \\
\hline "Taunayia” sp. & Toca do Gonçalo Cave (BA) & 5 & - \\
\hline Astyanax $c f$. jordani & Comercial breeding & 4 & + \\
\hline
\end{tabular}




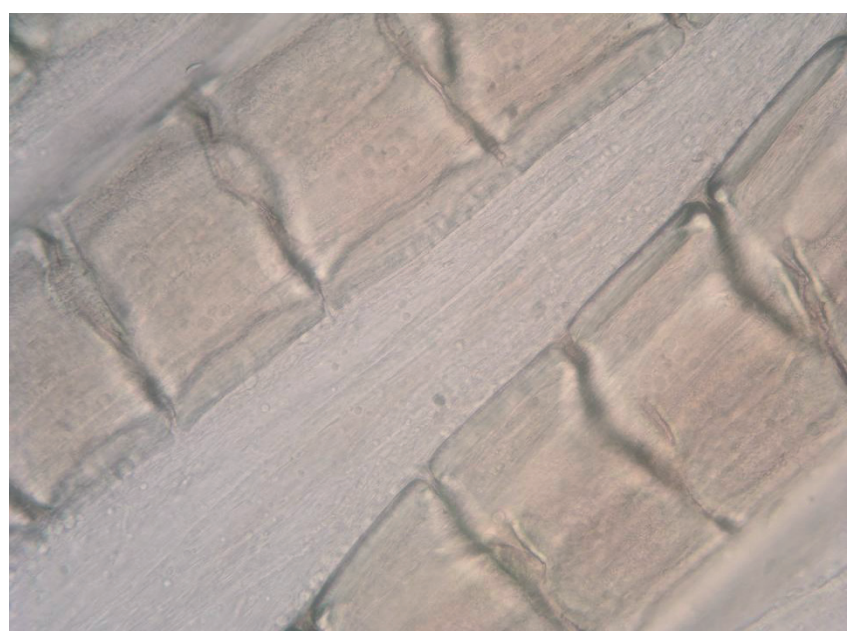

Fig. 1. Detail of the caudal-fin of a specimen of Stygichthys typhlops before the administration of L-DOPA (control); melanophores are not visible. Magnification $250 \mathrm{x}$.

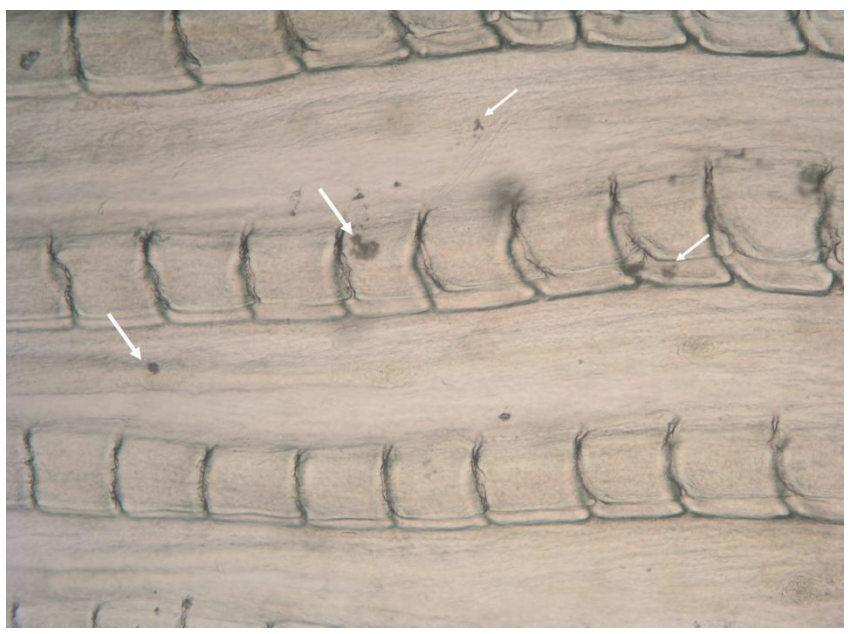

Fig. 2. Detail of the caudal-fin of the same specimen of Stygichthys typhlops after administration of L-DOPA; melanophores indicated by arrows. Magnification $200 \mathrm{x}$.

disruption of tyrosinase or TRP-1 function and/or increasing of tyrosinase proteasomal degradation (Yamaguchi et al., 2007). OCA types 2 and 4 are caused by disruption of the sorting of functional tyrosinase to melanosomes. Thus the types 2 and 4 of OCA conditions would correspond to the so-called "tyrosinase-positive albinism".

Brazilian DOPA $(+)$ species may correspond to any case of OCA albinism, because our methods do not allow for distinction among them. On the other hand, the presence of melanin cells, evidenced after the administration of L-DOPA to samples from Stygichthys typhlops, Ancistrus formoso, Rhamdiopsis sp, "Taunayia" sp. and Astyanax sp. (probably from La Chica Cave) indicates that these species are not homozygous for the polygenic additive system related to the differentiation of melanophores.

On the other hand, the discontinuous distribution of the depigmented versus pigmented phenotypes in T. itacaram-

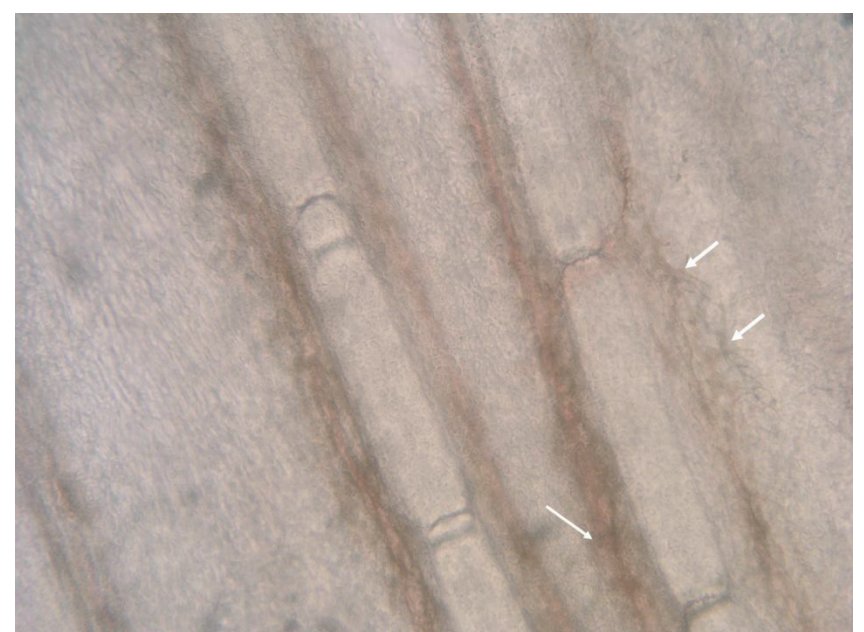

Fig. 3. Detail of the caudal-fin of a pigmented specimen of $T$. itacarambiensis, not treated with DOPA. Magnification 200x.

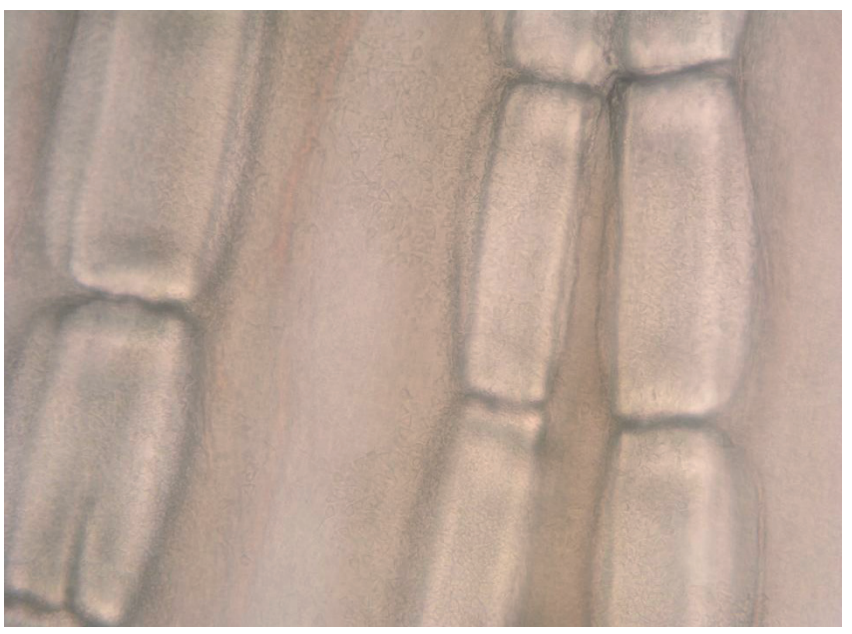

Fig. 4. Detail of the caudal-fin of a DOPA(-) albino specimen of T. itacarambiensis, not treated with DOPA. Magnification $200 \mathrm{x}$.

biensis (1/3 versus $2 / 3$ of the population; Trajano \& Pinna, $1996)$ is consistent with a monogenic, recessive model of inheritance of depigmented phenotypes, not with an additively polygenic one. Otherwise, the high proportion of completely depigmented fish is inconsistent with the expected for the frequency of this extreme phenotype within a polygenic system. Because the depigmented individuals are irresponsive to L-DOPA, mechanisms might be involved in the loss of their ability to synthesize melanin. Some possibilities include gene mutations leading to an increase of tyrosinase degradation, disruption of tyrosinase function, or the loss of the ability to convert L-DOPA into melanin due to a blocking of some step downstream of L-DOPA synthesis in the melanogenic pathway of these albino specimens. In mammals, similar condition results from the disruption of tyrosinase or TRP-1 function and causes oculocutaneous albinism (OCA) type 1 (tyrosinase-negative) or type 3 (TRP-1), with absence or reduction of melanin pigment by melanocytes in the skin, hair follicles, and eyes. This corresponds to a DOPA (-) con- 
dition (sensu Oetting \& King 1999; Toyofuko et al., 2001; Yamaguchi et al., 2007). However, intensive bioquemistry and genetic research are required in order to classify pigmentation disorders of these teleosts according to the level of knowledge of mammalian disorders.

It is noteworthy that an individual variation in color is observed within the pigmented part of the T. itacarambiensis population, with some fish visibly paler than others, indicating that such individuals are heterozygous as regards to the polygenic system involved in the determination of the number/ density of melanophores. Moreover, the same proportions of specimens with eyes reduced but still visible externally are observed in the two parts of the population (Trajano \& Pinna, 1996), the eyes of depigmented fish being red, as in classical albino mammals. Therefore, it is reasonable to infer that the depigmented part of the population is also heterozygous in relation to the polygenic system, but the melanin cells are colorless.

The case with Rhamdiopsis sp.2 ("Taunayia" sp.) is more complicated. The studied specimens were either true DOPA (-), as part of the T. itacarambiensis population, or homozygous for the polygenic system controlling the number of chromatophores, i.e., they lost the ability to produce pigment cells, or both. Within a neutralistic, gradualistic genetic context as that exposed by Wilkens (1988) for troglobitic Astyanax, the fixation of the mutations throughout the population would be slower for polygenic additive systems (such as that proposed for the number/density of melanophores) than for the monogenic, recessive system hypothesized for the loss of ability to synthesize melanin. Rhamdiopsis sp. 2 seems to be a basal clade within the genus, whereas Rhamdiopsis sp.1 has a more apical position in the phylogeny (F. A. Bockmann, pers. comm.). The high degree of morphological specialization of Rhamdiopsis sp.2, associated with its putative basal position in the Rhamdiopsis phylogeny, points to an older age for this lineage (Trajano, 2007), which is consistent with both theories regarding the depigmentation.

In conclusion, our data point to the occurrence of different genetic mechanisms of melanin reduction in troglobitic fishes, which may co-exit in the same species: a polygenic system would be involved in the differentiation of melanophores, determining their density in the skin, and monogenic systems would be involved in the ability to synthesize melanin, which could be lost due to the blocking of different steps in this syntheses. Both morphological and physiological melanin reduction is observed in T. itacarambiensis, that differ from most studied depigmented troglobitic fishes, including other Brazilian species and an Astyanax cave population, by the fact that the blockage in the melanogenic pathway seems to occur downstream (not upstream) the tyrosinase dependent steps.

For a first approach to this problem, tests in vitro with LDOPA using fin clippings are simple, quick and informative, and particularly adequate to the generally small subterranean fish populations, because fins regenerate, thus it is not necessary to dispose the fish and repetitions are possible using the same specimens.

\section{Acknowledgements}

We are greatly indebted to the several speleobiologists and cavers who have been helping us in the field along these years, to the anonymous referee for his(her) useful comments and criticisms, and to the Fundação de Amparo à Pesquisa do Estado de São Paulo - FAPESP, for the research grant (\# 03/00794-5). MAV and ET are partially supported by the Conselho Nacional de Desenvolvimento Científico e Tecnológico - CNPq (fellowships \# 305946/06-4 and 302174/2004-4, respectively). Permission for collections was given by IBAMA.

\section{Literature Cited}

Hirobe, T. 1982. Origin of melanosome structures and cytochemical localizations of tyrosinase activity in differentiating epidermal melanocytes of newborn mouse skin. Journal of Experimental Zoology, 224: 355-363.

Jeffery, W. R. 2006. Convergence of pigment regression in cave animals: developmental, biochemical, and genetic progress toward understanding evolution of the colorless phenotype. p. 38. In: Moldovan, O. T. (ed.). XVIII ${ }^{\text {th }}$ International Symposium of Biospeleology - 100 years of Biospeleology, Cluj-Napoca, SIBIOS - Société Internationale de Biospéologie [abstracts].

Jimbow, K., C. Hua, P.F. Gomez, K. Hirosaki, K. Soda, T.G. Salopek, H. Matsusaka, H.Y. Jin \& T. Yamashita. 2000. Intracellular vesicular trafficking of tyrosinase gene family protein in eu- and pheomelanosome biogenesis.Pigment Cell Research, 13 (sup.8): 110-117.

Mattox, G. M. T., M. E. Bichuette, S. Secutti, \& E. Trajano. 2008. Surface and subterranean ichthyofauna in the Serra do Ramalho karst area, northeastern Brazil, with updated lists of Brazilian troglobitic and troglophilic fishes. Biota Neotropica, 8(4).

McCauley, D. W., E. Hixon \& W. R. Jeffery. 2004. Evolution of pigment cell regression in the cavefish Astyanax: a late step in melanogenesis. Evolution \& Development, 6: 209-218.

Mishima, Y. 1960. New technic for comprehensive demonstration of melanin, premelanin and tyrosinase sites. Combined DOPApremelanin reaction. Journal of Investigative Dermatology, 34 : 355-360.

Oetting, W. S. \& R. A. King. 1999. Molecular basis of albinism: mutations and polymorphisms of pigmentation genes associated with albinism. Human Mutation, 13: 99-115.

Protas, M. E., C. Hersey, D. Kochanek, Y. Zhou, H. Wilkens, W. R. Jeffery, L. I. Zon, R. Borowsky \& C. J. Tabin. 2006. Genetic analysis of cavefish reveals molecular convergence in the evolution of albinism. Nature Genetics, Letters, 107-111.

Reis, R. E., E. Trajano \& E. Hingst-Zaher. 2006. Shape variation in surface and cave populations of the armoured catfish Ancistrus (Siluriformes: Loricariidae) from the São Domingos karst area, Upper Tocantins River, Brazil. Journal of Fish Biology, 68: 414-429.

Toyofuku, K., I. Wada, J. C. Valencia, T. Kushimoto, V. J. Ferrans \& V. J. Hearing. 2001. Oculocutaneous albinism types 1 and 3 are ER retention diseases: mutation of tyrosinase or Tyrp1 can affect the processing of both mutant and wild-type proteins. The FASEB Journal, 15: 2149-2161.

Trajano, E. 2001. Ecology of subterranean fishes: an overview. Environmental Biology of Fishes, 62(1-3): 133-160.

Trajano, E. 2003. Ecology and ethology of subterranean catfishes. Pp. 601-635. In: Arratia, G., B. G. Kapoor, M. Chardon \& R. Diogo (eds.). Catfishes, v. 2. Science Publishers, Enfield. 812p. 
Trajano, E. 2005. Evolution of Lineages, p. 230-234. In: Culver, D. C. \& W. B. White (eds.). The Encyclopedia of Caves. Elsevier Academic Press, San Diego. 654p.

Trajano, E. \& M. E. Bichuette. 2005. Diversity of subterranean fishes in Brazil. Pp. 161-163. In: Gibert, J. (ed.). World Subterranean Biodiversity, Proceedings of an International Symposium held on 8-10 December 2004, in Villeurbaine.

Trajano, E. 2007. The challenge of estimating the age of subterranean lineages: examples from Brazil. Acta Carsologica, 36(1): 191-198.

Trajano, E. \& F. A. Bockmann. 1999. Evolution of ecology and behaviour in Brazilian cave Heptapterinae catfishes, based on cladistic analysis (Teleostei: Siluriformes). Mémoires de Biospéologie, 26: 123-129.
Trajano, E. \& M. C. C. Pinna. 1996. A new cave species of Trichomycterus from Eastern Brazil (Siluriformes, Trichomycteridae). Revue française d'Aquariologie, 23(3-4): 85-90.

Trajano, E., R. E. Reis \& M. E. Bichuette. 2004. Pimelodella spelaea, a new cave catfish from Central Brazil, with data on ecology and evolutionary considerations (Siluriformes: Heptapteridae). Copeia, 2004(2): 315-325.

Wilkens, H. 1988. Evolution and genetics of epigean and cave Astyanax fasciatus (Characidae, Pisces). Evolutionary Biology, 23: 271-367.

Yamaguchi, Y., M. Brenner \& V. J. Hearing. 2007. The regulation of skin pigmentation. Journal of Biological Chemistry, 282: 27557-27561.

Accepted July 2008

Published December 22, 2008 